\title{
Learning during the new financial service innovation process: antecedents and performance effects
}

Citation for published version (APA):

Blazevic, V., \& Lievens, A. (2003). Learning during the new financial service innovation process: antecedents and performance effects. METEOR, Maastricht University School of Business and Economics. METEOR Research Memorandum No. 023 https://doi.org/10.26481/umamet.2003023

Document status and date:

Published: 01/01/2003

DOI:

10.26481/umamet.2003023

Document Version:

Publisher's PDF, also known as Version of record

\section{Please check the document version of this publication:}

- A submitted manuscript is the version of the article upon submission and before peer-review. There can be important differences between the submitted version and the official published version of record. People interested in the research are advised to contact the author for the final version of the publication, or visit the DOI to the publisher's website.

- The final author version and the galley proof are versions of the publication after peer review.

- The final published version features the final layout of the paper including the volume, issue and page numbers.

Link to publication

\footnotetext{
General rights rights.

- You may freely distribute the URL identifying the publication in the public portal. please follow below link for the End User Agreement:

www.umlib.nl/taverne-license

Take down policy

If you believe that this document breaches copyright please contact us at:

repository@maastrichtuniversity.nl

providing details and we will investigate your claim.
}

Copyright and moral rights for the publications made accessible in the public portal are retained by the authors and/or other copyright owners and it is a condition of accessing publications that users recognise and abide by the legal requirements associated with these

- Users may download and print one copy of any publication from the public portal for the purpose of private study or research.

- You may not further distribute the material or use it for any profit-making activity or commercial gain

If the publication is distributed under the terms of Article $25 \mathrm{fa}$ of the Dutch Copyright Act, indicated by the "Taverne" license above, 


\title{
Learning during the New Financial Service Innovation Process: Antecedents and
}

\section{Performance Effects}

\author{
Vera Blazevic and Annouk Lievens ${ }^{1}$
}

- ${ }^{1}$ Vera Blazevic is a Ph. D candidate at Maastricht University, Faculty of Economics and Business Administration, Department of Marketing and Market Research, Postal address, P.O. Box 616, 6200 MD Maastricht (The Netherlands), Tel.: 31-43-3883716/ Fax: 31-43-3884918, E-mail: v.kalthofer@mw.unimaas.nl .

- Annouk Lievens is an Associate Professor of Marketing at Antwerp University (UFSIA), Faculty of Applied Economic Sciences, Department of Marketing, Prinsstraat 13, 2000 Antwerp (Belgium), Tel.: 32-3-2204064/Fax: 32-3-2204067,E-mail: annouk.lievens@ua.ac.be. 


\title{
Learning during the New Financial Service Innovation Process: Antecedents and Performance Effects
}

\begin{abstract}
This article theoretically and empirically examines the antecedents and consequences of project learning during the new financial service innovation process. We analyze the impact of project learning on project performance and performance of the financial institution. Next we investigate the antecedent role of the nature of communication and organizational design on project learning. Following the development of a propositional framework, a survey research has been developed within the Belgian banking industry. Our research findings indicate that the level of project learning contributes to the corporate reputation of the financial institution. Moreover, learning during project innovation enhances the cost and the competitive position of the innovating bank. Our study empirically supports the crucial influence of management support, harmonious cross-functional interfaces, organizational diversity and participative decisionmaking on the level of project learning. Both innovative and coordinative communication are needed to balance the information needs throughout the innovation process. However, our findings underline the fact that the impact of innovative communication on the level of project learning is contingent upon the quality of the planning stage. The up-front activities of the innovation process seem to have an important leveraging effect on learning, and hence on project and bank performance.
\end{abstract}




\section{Introduction}

In the past, financial service firms experienced a relatively stable competitive environment as the financial service sector was highly regulated. However, in recent years the competitive environment has become increasingly dynamic as a result of deregulation and redrawn boundaries (de Brentani, 1993; Drew, 1994; Thwaites, 1992; Morgan, Cronin and Severn, 1995; Storey and Easingwood, 1993). The deregulation of the EC 1992 provisions shifted traditional boundaries eliminating entry barriers in non-traditional sectors. Therefore, financial service firms are able to reach new customers with new service offerings. Despite the new opportunities, the redrawn boundaries have also resulted in an amplification of domestic competition from foreign companies (Storey and Easingwood, 1993; Drew, 1994) and other business sectors. Consequently, competition has intensified in recent years because of these new market dynamics. As companies have to cope with these new dynamics, organizations have to become more effervescent and flexible so that they are able to react to market changes and adapt their activities accordingly.

Therefore, in order to survive and stay competitive in the increasingly dynamic environment, organizations should be sensitive to emergent changes, encourage the usage of knowledge management and foster learning (Tsang, 1997; Sinkula, Baker and Noordewier, 1997; Scarbrough and Lannon, 1988; Bartlett and Ghoshal, 1998; Jarvenpaa and Ives, 1994). Another critical factor in managing adaptiveness and change is the innovative capacity of an organization (de Brentani, 1993; Drew, 1994; Easingwood and Storey, 1991; Cooper et al., 1994). Organizations need to learn to preserve and anticipate major technological, competitive and customer trends. Organizational learning is vital to the survival of the organization and critical especially during innovation as it steers the transformation of technological and market information into market-demanded outcomes (Lievens, de Ruyter and Lemmink 1999).

Recent innovation studies have mainly considered the factors contributing to new financial service success and failure (Storey and Easingwood, 1993; de Brentani 1989, 1993; Cooper et al., 1994; Edgett and Jones, 1991, Edgett and Parkinson, 1994; Easingwood and Storey, 1991). Except for Slater and Narver (1995b) and Hult and Ferrell (1997a) very little research attention has been given to the mediating role of organizational learning. Slater and Narver (1995b) provide a conceptual framework that contemplates organizational learning as the mediator between the antecedent role of culture and climate and several outcome variables, such as customer satisfaction, new product success, sales growth and profitability. Additionally, Hult and Ferrell (1997a) present an empirical point of view of the mediating role of organizational learning in the purchasing process within the SBUs of a multinational corporation where openness and localness are the antecedents and the level of customer orientation is the outcome of organizational learning. Despite the contribution of these studies, research on the role and consequences of learning in a service innovation context is limited. Therefore, this paper will focus on the antecedents and consequences of project learning during new financial service innovation.

We will consider two major antecedents: (1) the nature of communication, and (2) organizational design during the innovation process. We examine communication as a very important facilitating condition for learning. Indeed, several studies have shown that communication is an important issue in new service development (Lievens, Moenaert and 
S'Jegers, 1999; Lievens and Moenaert, 2000b; de Brentani, 1989, 1993; Easingwood and Storey, 1991) whereas little empirical research has been published that investigate communication and learning. In addition, several studies exist that link organizational design variables to new service development (Thwaites, 1992; Moenaert et al., 1992; Edgett, 1994; Van de Ven, 1986; Ennew and Wright, 1990; Johne and Harborne, 1985) whereas only a few studies relate organizational design and learning (Sinkula, Baker and Noordewier, 1997; McGill, Slocum and Lei, 1992; Slater and Narver, 1995b). Therefore, we aim to contribute to our research problem by studying how to design the organizational system in the financial service sector in order to achieve a high level of learning on the project level.

Following our research problem, a major question pertains to the performance effects of learning. Here, we investigate the link between learning and unique performance measures within the financial services industries. We will distinguish between organizational performance measures, i.e. corporate reputation, competitive position and cost position (de Brentani, 1989; Easingwood and Percival, 1990; Johne and Storey, 1998; Sinkula, Baker and Noordewier, 1997; Easterby-Smith, 1997) and performance measures related to the project itself, i.e. cross-selling and the increase of service delivery capacity (Johne and Storey, 1998; Easingwood and Percival, 1990).

This article will be structured as follows. We start with our theoretical model and develop a propositional framework on the antecedents and consequences of project learning during new financial service innovation. Next we describe the research design that was set up to validate our conceptual framework. Following the discussion of our results, we formulate the major conclusions and management implications of our study.

\section{Theoretical Model}

\section{Learning during New Financial Service Innovation: building a knowledge base}

Our foremost aim is to contribute to how learning can be enhanced during the innovation process of banking services. Throughout the development of our conceptual framework we adopt an information processing view. Consistent with the information processing perspective of organizations, we consider the studied banks and their respective project innovation teams to be information systems (Moorman, 1995; Daft and Weick, 1984; Shivastrava, 1983, Ribbens, 1997; Sinkula, 1994; Edmondson, 1999, Hult and Ferrell, 1997a) that develop organizational knowledge (Duncan and Weiss, 1979; Seufert, van Krogh and Bach, 1999; Ribbens, 1997; Schein, 1993). Thus, the knowledge base of the innovation project team emerges from the information processing activities during the innovation process.

Consequently, we adopt the perspective that organizational learning is the development of a knowledge base (Shivastrava, 1983; Hult and Ferrell, 1997a). Duncan and Weiss (1979, p. 84) conceive knowledge as the outcome of learning and describe organizational learning "as the process within the organization by which knowledge about action-outcome relationships and the effect of the environment on these relationships is developed." The innovation task can be considered an organizational activity directed at the creation of a knowledge base. The knowledge that is created is the result of a process involving the acquisition, the distribution and the interpretation of knowledge (Huber, 1991; Moorman, 1995; Slater and Narver, 1995b; 
Duncan and Weiss, 1979; Lant and Mezias, 1992; Nevis, DiBella and Gould, 1995; Sinkula, 1994; Hult, 1998). Organizational learning involves joint contributions of individuals towards organizational problems. Thus, an organization's ability to learn depends on the experience, ability and actions of individuals (Argyris and Schon, 1978; Helfat, 1994; Kim, 1993). Indeed, we may consider the innovation task as an organizational activity directed at organizational effectiveness. Both individuals and groups are the resources that have to be managed towards organizational effectiveness. Thus, individual performance will contribute to group performance and this will in turn enhance organizational performance (Gibson, Ivancevich and Donnelly, 1988). As a result, understanding group behavior as well as individual behavior is critical for effective innovation management. In our research our focal unit of analysis is the innovation project. Therefore, we will focus on project learning, i.e. a group perspective of learning (Edmondson, 1999). Individuals's actions are based on a set of shared mental models. In this respect, groups can be viewed as a collective individual with their own set of mental models contributing to the shared mental models and hence learning of the organization (Kim, 1993). Through the process, the various experiences of the individuals in the innovation group are bundled through information exchange and organizations are able to exploit the new insights. Learning should be seen as a necessary process involving reciprocal exchanges between individual employees (Easterby-Smith, 1997; Bartlett and Ghoshal, 1998).

Thus, from a system's perspective we need insight into the organizational knowledge creating processes to explain the information processing behavior at the individual or group level. Moreover, if we take the view that learning is a cumulative process, individual, group and organizational learning strongly overlap. Indeed, accumulated prior knowledge will enhance learning (Cohen and Levinthal, 1990; DiBella, 1995; Crossan, Lane and White, 1999) and individuals, groups and the organization will "tap" knowledge from each other.

Organizational learning is complex, occurs at different cognitive levels and involves multiple subprocesses (Slater and Narver, 1995a; Sinkula, 1994, Hult, 1998; Tsang, 1997; Hult and Ferrell, 1997b). Acquisition relates to the process by which information is obtained. This may be related to direct experience, experiences of others and the existing knowledge base of the organization (Slater and Narver, 1995; Kogut and Zander, 1992; Schein, 1993; Sinkula, 1994; Hult and Ferrell, 1997a). The latter has been referred to by Kogut and Zander (1992, p. 384) as the concept of "combinative capability". They state that learning will depend upon the current and already acquired knowledge of the firm. The same reasoning is adopted within organizational learning ${ }^{1}$ literature through the construct of "organizational memory" (Levitt and March, 1988; Huber, 1991; Nevis, DiBella and Gould, 1995; Sinkula, Baker and Noordewier, 1997) including "everything that is contained in an organization that is somehow retrievable" (Kim, 1993, p. 43). As a result, information acquisition does not only involve bringing information about the external environment into the organization, but must be extended to the use of existing knowledge within the organization. Distribution of information refers to the process of information dissemination between different information sources (Huber, 1991; Daft and Weick, 1984; Slater and Narver, 1995; Sinkula, Baker and Noordewier, 1997; Hult, 1998). Through the sharing of information a stock of knowledge is created which becomes part of the "organizational memory" (Levitt and March, 1988; Nevis, DiBella and Gould, 1995; Kogut and Zander, 1992; Huber, 1991). As Huber

\footnotetext{
${ }^{1}$ Indeed, concepts relating to "combinative capability" (Kogute and Zander, 1992), " organizational memory" (e.g., Huber, 1991) and "absorptive capacity" (Cohen and Levinthal, 1990) relate to the whole learning process involving acquisition, dissemination and interpretation of knowledge.
} 
(1991, p. 100) stated it "... But when information is widely distributed in an organization, so that more and more varied sources for it exist, retrieval efforts are more likely to succeed and individuals and units are more likely to be able to learn." As a result, learning within the organization is enhanced as sharing differentiates organizational from individual learning (Kim, 1993; Daft and Weick, 1984). Interpretation occurs when information becomes meaningful by sharing perceptions and building cognitive maps (Daft and Weick, 1984; Levitt and March, 1988; Moorman, 1995; Dunn, 1986; Sinkula, Baker and Noordewier, 1997; Hine and Goul, 1998; Hult, 1998). Slater and Narver (1995b, p. 65) point to the importance of "shared interpretation of the information" as an antecedent condition for organizational learning to happen. Groups and individuals have to obtain a consensus on the meaning of the information and its consequences for action-outcome relationships. A shared language is created by which individuals within the organization can communicate (Kogut and Zander, 1992).

\section{Learning Antecedents: The Nature of Communication}

Learning is not possible without communication (Lei, Slocum and Pitts, 1999) as communication is a prime factor for learning. Without information exchange, employees cannot learn from other experts and the process of knowledge acquisition and sharing would be inhibited (Ribbens, 1997; Schein, 1993). As Duncan and Moriarty (1998, p.2) describe: "Communication is the human activity that links people together and creates relationships. It is at the hart of meaning-making activities. [...] It serves as a way to develop, organize, and disseminate knowledge." We adopt the definition of communication provided by Rogers and AgarwalaRogers (1976, p.9): "Communication is the process by which an idea is transferred from a source to a receiver with the intention of changing his or her behavior." Such behavioral effects may consist of changes in knowledge, changes in attitude as well as changes in overt behavior (Rogers and Agarwala-Rogers, 1976). We define effective communication as those changes in information receiver behavior that were intended by the information source (Rogers and Shoemaker, 1971; Rogers and Agarwala-Rogers, 1976). In line with an information processing perspective, we conceptualized the project innovation team within financial organizations as information processing systems that have to attend to work-related uncertainty (i.e., the innovation task). As a result, following our definition on communication, we consider the effect of communication to be cognitive, equivalent to the creation of a knowledge base (i.e., project learning). Indeed, innovation team members, being part of the marketing department, may be viewed as pockets of knowledge (Souder and Moenaert, 1992). Information exchange within such a team helps team members to "tap" these pockets of knowledge (i.e., coordinative and innovative communication). However, innovative performance will also depend on information originating from outside the innovating unit. As a result, innovation team members also "tap" information originating from other departments (i.e., crossfunctional interface). Project learning, will therefore be contingent upon the type of communication flows. We adopt the twodimensional classification of Hauptman (1986) to describe the nature of communication throughout the innovation process, i.e. innovative and coordinative communication.

Innovative communication involves creativity in problem solving leading to new idea generation (Souder and Moenaert, 1992) and should act as a stimulus for new service development. Innovative communication can also be linked to Greenbaum's classification (1974, p. 742) of the innovative communication network. An organization that incorporates such an innovative communication network will be capable to adapt to internal and external stimuli. 
Thus, such an organization is actively involved in problem solving and new idea processing leading to increased learning behavior. Through innovative communication, employees become sensitive to creative thinking, which results in innovative initiation processes throughout the whole company. De Brentani (1993, p. 19) claims that "personnel at all levels need to think in innovative terms". Consequently, we postulate the following proposition:

Proposition 1: The level of innovative communication relates positively to the level of project learning.

Coordinative communication mainly attempts the exchange of information concerning the matching of task-related interdependencies between different project members (Souder and Moenaert, 1992). Coordinative communication has many common characteristics with Greenbaum's (1974) regulative communication. According to Greenbaum (1974), regulative communication relates to controls, orders, direction and feedback between subordinates and superiors and across functional units. Coordinative communication should help to integrate experts with different knowledge foci into an innovation team. It should help to avoid problems in the management of development projects. Edvardsson et al. (1995) have found that a lack of clarity in who owns the project will lead to intra-organizational conflicts and coordination problems. Consequently, coordinative communication is needed to facilitate effective learning. Thus, we expect the following:

Proposition 2: The level of coordinative communication relates positively to the level of project learning.

\section{The Moderating Impact of the New Service Innovation Process}

A key success factor in developing new financial services is the proficiency of the activities in the new development process (de Brentani, 1993). Moreover, communication between employees from different departments is of major importance to involve all possible experts during the new financial service innovation process (Lievens, Moenaert and S'Jegers, 1999).

Although Johne and Storey (1998) claim that quality of the development process is of major importance in studies of new service development, research so far is limited with respect to the quality of the individual process stages. We divided the new service development process in three different stages (Lievens, Moenaert and S'Jegers, 1999): (1) a planning stage involving the upfront, pre-development activities, (2) a development stage consisting of the design, development and testing activities, and (3) a launch stage containing pre-launch and launch activities. Several researchers already detected that the quality of the planning stage has a major impact on the subsequent new service innovation process (Cooper and Kleinschmidt, 1986; Edvardsson et al., 1995; Moenaert et al., 1995; Lievens, Moenaert and S'Jegers, 1999). Previous research has indicated that the quality of the communication during the planning stage has an important leveraging effect on the quality of subsequent activities. Lievens, Moenaert and S'Jegers (1999) emphasize the importance of communication during the new financial service innovation process. This leveraging effect may explain the existence of a path dependency effect where accumulated expertise acquired during the planning stage is transferred to the development and launch stage. 
Therefore, the quality of activities during the planning stage determines the activities in the subsequent stages.

Furthermore, product innovation studies have also pointed to the importance of up-front activities (Moenaert et al., 1995). Therefore, we can link the nature of communication to the different stages of the innovation process. Souder and Moenaert (1992) found that innovative communication should be the center of focus in the planning stage whereas coordinative communication should be more used in the development and launch stage. In the planning stage, more creative thinking is needed than in the other two stages as idea generation is an important task in this first stage. Consequently, innovative communication has a major effect on the quality of the planning stage. After the planning stage, the activities in the new service development process need more coordination as the creative process is finished and the selected ideas have to be elaborated and exploited. Thus, in the development and launch stage coordinative communication is needed. Hence, we postulate the following propositions:

Proposition 3 [a]: The quality of the planning stage positively moderates the impact of innovative communication on the level of project learning.

Proposition 3 [b]: The quality of the development and the launch stage positively moderates the impact of coordinative communication on the level of project learning.

\section{Learning Antecedents: Organizational Design}

The successful development of new services is not a matter of luck but it is the consequence of well coordinated organizational activities (de Brentani, 1993). Learning must be stimulated through an organizational design that not only facilitates learning possibilities but rather encourages active learning behavior. As learning should contribute to business success, it is a necessary requirement for companies to create a fast, agile and boundaryless organizational setting in order to stay competitive (Tucker et al., 1996). To strengthen a company's competencies, financial service firms supporting an internal environment that stimulates learning need support from top management (Lei, Slocum and Pitts, 1999; Drew, 1994; Bartlett and Ghoshal, 1998) and must engage in cooperative efforts (Drew, 1994; Bartlett and Ghoshal, 1998; McGill, Slocum and Lei, 1992). Moreover, employees should be allowed to participate in decision-making (Drew, 1994; Bouwen and Fry, 1991) and experts from different functions should be integrated in the project team (Bouwen and Fry, 1991; McGill, Slocum and Lei, 1992). Therefore, we will investigate the following organizational antecedents: top management support, cross-functional interfaces, organizational diversity and participation in decision-making.

Management support has a strong influence on the learning efforts during the new service development process (Lei, Slocum and Pitts, 1999). An organization's capability to establish knowledge diffusion and stimulate intraorganizational learning often could not start until top management reconceptualized their cognitive thinking (Bartlett and Ghoshal 1998; EasterbySmith, 1997). Management support shows the importance of knowledge exchange within the innovation project. Top management must function as a motivator that believes in achieving competitive advantage through a high learning commitment (Slater and Narver 1995b; Jaworski and Kohli, 1993; Garvin, 1993). Thus, through a strong management support, the motivation of the innovation project team members to engage in information processing activities is increased. 
Without commitment from the top, it is impossible to establish favorable learning scenery in an organization (Senge, 1990). Top management support shows the importance of a certain project and will thus lead to a higher willingness to share information. Hence, we can formulate the following proposition:

Proposition 4: The level of project learning relates positively to the level of top management support.

Financial services are mainly characterized by four features: (1) products are information, service and knowledge intensive, (2) environment is dynamic, (3) choices are complex and organizations have to consider many facets, and (4) customer service quality is a critical success factor (Drew, 1994). In order to achieve a high level of learning which can be further exploited, the different functional units must work together and cross-functional interfaces must be established to involve the different functions in the information processing activities. Moreover, financial service firms are process intensive (Drew, 1994) as it is impossible to decouple the marketing and production activities due to the inseparability of production and consumption of services (Grönroos, 1990; Gummesson, 1987; Lievens and Moenaert, 2000a). Consequently, different areas of expertise are prevalent in the various functional units that can be integrated via cross-functional interfaces. These cross-functional interfaces link the strategic and operational learning processes (Easterby-Smith, 1997; Mahajan et al., 1994; Pinto, Pinto and Prescott, 1993). The combination of different activities is a prerequisite for learning (Easterby-Smith, 1997; Seufert, van Krogh and Bach, 1999). Moreover, cross-functional interfaces lead to a higher thoroughness of learning as the different functional group members develop a shared interpretation. Huber (1991, p. 90) reveals that "more organizational learning occurs when more organizational units develop uniform comprehensions of the various interpretations". Consequently, cross-functional cooperation between functional units has a major positive impact on learning. Pinto, Pinto and Prescott (1993, p. 1294) claim that "the carryover effects from previous experiences on cross-functional teams may influence both project team members' willingness to cooperate and project outcomes". Therefore, cross-functional interfaces stimulate creativity expanding the knowledge horizons and reducing barriers between the functions (Tucker et al., 1996). In sum, we expect the following.

Proposition 5: The level of project learning relates positively to the level of cross-functional interfaces.

Organizational diversity is defined as the number of specialists in an organization and their professionalism (Rogers and Agarwala-Rogers, 1976). Organizational diversity increases as the number of various specialists in an organization proliferates. This heterogeneity leads to a better stimulation of new ideas and the specialists can gain new insights through different perspectives (Easterby-Smith, 1997; Garvin, 1993). Thus, more possibilities to learn are persistent. As different perspectives involve more knowledge, supplementary alternatives are evaluated where a higher degree of synthesizing leads to more solutions (Carroll and Hannan, 2000). A higher degree of organizational diversity leads to many varied interpretations and as a consequence a higher elaborateness of learning is developed that changes the range of potential behaviour (Huber, 1991). Through organizational diversity the innovation project team starts from many different perspectives leading to a higher learning of the innovation team, as they are involved in more information processing activities. Van de Ven (1986, p. 598) states that it is positive for 
learning to "divide the labor among specialists who are best qualified to perform unique tasks and then to integrate the specialized parts to recreate the whole. The objective of course is to develop synergy in managing complexity and interdependence with an organizational design where the whole is greater than the sum of its part". Consequently, we postulate the following proposition:

Proposition 6: The level of project learning relates positively to the level of organizational diversity.

Another important antecedent of learning is participative decision-making. Tucker et al. (1996) state that participative decision making is a requirement for an effective learning organization. If employees can participate in the decision-making process, their motivation is higher to engage in learning activities. Learning will enable them to perform better in the future as their personal knowledge base broadens. Therefore, learning leads to an improvement in motivation for task accomplishment leading to a higher self-efficacy (Conger and Kanungo, 1988; Spreitzer, 1995; Leonard-Barton, 1992). Hence, participative decision-making leads to a higher motivation to learn. Moreover, creative thinking is stimulated that will lead to new ideas which is especially important in an innovation project team (Hurley and Hult, 1998). As employees possess a higher motivation to learn their commitment to share knowledge proliferates. Moreover, the active involvement reduces change-averse behavior, as the employees themselves are the initiators of change (Leonard-Barton, 1992). Additionally, they can overcome inertia (Van de Ven, 1986), which stimulates an active project climate. A favorable project climate in turn results in joint problem solving, which has a positive effect on learning. Consequently, we deduce the following proposition:

Proposition 7: The level of project learning relates positively to the level of participative decision-making.

\section{Learning Consequences: New Financial Service Performance}

An organization that is capable of reacting to environmental changes in a fast manner is able to surpass competitors that rarely learn from past behavior. As a consequence learning will improve organizational performance in the future (Slater and Narver, 1995a; Hurley and Hult, 1998). Thus, the impact of learning should be assessed using various performance measures (Sinkula, Baker and Noordewier, 1997; Tsang, 1997; Prahalad and Hamel, 1990; Garvin, 1993). Several specific performance outcomes have been conceptualized and operationalized within previous research of financial service industries. These performance measures include corporate reputation (de Brentani, 1989; Easingwood and Percival, 1990), competitive position (Johne and Storey, 1998; Sinkula, Baker and Noordewier, 1997), cost position (Easterby-Smith, 1997), cross-selling (Johne and Storey, 1998) and service delivery capacity (Easingwood and Percival, 1990).

Corporate reputation is of major importance in the financial service sector as the service itself is difficult to differentiate and easy to imitate. Therefore, financial organizations are able to differentiate their service via its corporate reputation (Drew, 1994). In the increasingly dynamic financial environment, also fostered by the new economy, financial organizations should have a reputation for being well informed and up-to-date. "A learning culture is valuable to a firm's customers because that learning is directed toward understanding and effectively satisfying their 
current and latent needs through new products, services and ways of doing business. This should lead to 'positional sources of advantage' such as greater new product success, superior customer retention and higher customer-defined quality" (Slater and Narver, 1995a, p. 231). An organization can also benefit from promoting a reputation for innovativeness (Johne and Storey, 1998). As good learning capabilities are the basis for reacting quickly to environmental changes, learning can serve the purpose to broaden or improve the corporate reputation. Therefore, we deduce the following proposition:

Proposition 8: The corporate reputation of the innovating financial institution relates positively to the level of project learning.

Additionally, an organization can achieve strategic competitive advantage, if it is able to create and communicate knowledge effectively throughout the company (Tucker et al., 1996). Consequently, learning is also essential with respect to competitive position. The learning rate of an organization should at least equal the learning rate of competitors and the rate of environmental change in order to maintain a competitive position in the market (Sinkula, Baker and Noordewier, 1997; Easterby-Smith, 1997). A competitive position guarantees that the new service provides superior customer value. Thus, the organization can differentiate itself from competitors through the new service thereby creating a competitive advantage that is hard to imitate by competitor organizations. An organization that pursues an active learning strategy is more likely to demonstrate dynamic product development (Sinkula, Baker and Nordewier, 1997) and a better customer orientation (Hult and Ferrell, 1997a). The organization is able to develop distinctive capabilities via the diffusion of learning and the integration of knowledge. Therefore, it can achieve positions of advantage (Day, 1994). The focus on learning should help an organization to develop core competencies and a high degree of flexibility. If learning is successful, its effects can be exploited in the market and will improve the competitive position. We postulate the following proposition:

Proposition 9: The competitive position of the innovating financial institution relates positively to the level of project learning.

In relation to an improvement of the competitive position, institutions can also enhance their cost position via learning (Easterby-Smith, 1997; Lei, Slocum and Pitts, 1999). As learning includes the building of a knowledge base, information that has already been acquired can be stored in the organizational memory. Learning from the experience of innovation team members and using materials that have already been effective, improves the quality and speed of problem solving (Cross and Baird, 2000). Communication networks and organizational memories increase the mobility of information and knowledge so that stored information can be easily retrieved throughout the whole organization without incurring major time delays (Jarvenpaa and Ives, 1994). Therefore, information acquisition of already known problems is faster and thus more efficient, double-efforts can be avoided and already existing knowledge can be used more effectively preventing 'reinventing the wheel' (Drew, 1994). Moreover, through project learning employees get to know where to find necessary information, e.g. which colleague to ask for a specific problem, resulting in efficiencies in the problem-solving process (Cross and Baird, 2000). By embedding learning, companies can moreover reduce the information overload of employees, thus, enhancing the consistency and effectiveness of knowledge use throughout the organization. David Collis (1996) shows that organizational capability, which he defines as the 
"firm's collective tacit knowledge of how to initiate and respond to change"(Collis, 1996, p. 149), could be an independent source of profit. Additionally, Ghemawat and Ricart I Costa (1993) propose that in an innovation setting a knowledge-driven organization develops dynamic efficiency. Consequently, learning leads to efficient organizational behavior. Hence, we can formulate the next proposition:

Proposition 10: The cost position of the innovating financial institution relates positively to the level of learning.

Learning increases the competencies of an organization and a solid learning strategy fosters information exchange. Thus, learning may have a leveraging effect on future innovation projects because of increased organizational capacity and idea dissemination. Therefore, learning encourages the development of new services. These new services may attract new customers who might become users of other services provided by the same organization. Cross-selling occurs when new customers buy existing products (Easingwood and Percival, 1990). As the project innovation team is involved in information processing activities, the group members learn more about their customers and competitors. These new insights can be exploited when dealing with customers for existing products, too. Therefore, the cross-selling opportunities are expanded as the innovation team obtains more expertise. Consequently, cross-selling is another benefit of learning. This leads to the following proposition:

Proposition 11: The level of cross-selling of the innovating financial institution relates positively to the level of project learning.

As learning may have a leveraging effect on future innovation projects, the service delivery capacity is expected to increase as well. Easingwood and Percival (1990) found that the infrastructure (hardware, software, delivery systems) that has been developed for a certain project provide a platform for future service developments. Therefore, the service delivery capacity is interrelated to the cost position as an organization can exploit these infrastructure platforms. Moreover, a strong service delivery process is especially important in new financial services, as it is a key factor that customers value when evaluating an organization (Johne and Storey, 1998; Lievens, de Ruyter and Lemmink, 1999). In sum, we expect the following.

Proposition 12: The increase in service delivery capacity of the financial service innovation relates positively to the level of project learning.

The propositional framework has been summarized in Figure 1.

Take in Figure 1

\section{Research Method}

A survey research was developed to investigate the antecedents and consequences of learning during new financial service innovation. Our unit of analysis is the new financial service innovation project. Below the research design will be described. 


\section{Operationalization of the Constructs}

The above-presented constructs were operationalized according to the approach suggested by Churchill (1979), Peter (1979; 1981) and Peter and Churchill (1986). Three different sources were applied to build up a pool of items for each construct: (1) instruments published in the literature on innovation and service management, (2) proper case study results (Lievens, Moenaert and S'Jegers, 1999), and (3) new custom-designed scales for those constructs that were deficient in relevant operationalizations in the two former sources. Either a five-point Likert or a five-point rating scale was used to measure all constructs.

A pretest was employed in two leading Belgian banks in order to test the reliability of the constructs and to evaluate and improve the quality of the questionnaire prior to the large-scale data collection. One bank gave us information about 13 financial service innovation projects whereas the other bank provided us with a pool of 7 innovation projects.

In-depth interviews with two pretest respondents have been organized to address the following threats of internal validity:

1. Potential demand characteristics have been evaluated during the pretest, i.e. repondents' efforts to try to anticipate research objectives (Judd, Smith and Kidder, 1991; Campbell and Stanley, 1963)

2. Questionnaire scaling was checked on (i) potential "halo bias" (Cooper and de Brentani, 1984; Judd, Smith and Kidder, 1991; Nunnally and Bernstein, 1994) referring to the rater's tendency to systematically perceive an individual being high (low) in one area and thus being high (low) in other areas as well; and (ii) "social desirability" (Nunnally and Bernstein, 1994) or the rater's tendency to provide ratings reflecting socially desirable behaviors.

Cronbach's alpha was used to check the reliability of the multiple-item scales. A list of the constructs and the corresponding items of the final questionnaire is included in the appendix. Most constructs showed acceptable to high reliability estimates (Nunnally, 1967; Cronbach and Meehl, 1967). In constructing our measures we have used both qualitative (face validity through in-depth interviews and pre-testing) and quantitative assessment (Cronbach's alpha). Peter and Churchill (1986, p.4) indeed state that measure characteristics affect construct validity not only through reliability but also via content validity. Moreover, as Chronbach and Meehl (1967) suggest, in addition to trait validity measures have to be useful to make observable predictions derived from theory. Therefore, measures have to demonstrate nomological validity as well: "Nomological validity is based on the explicit investigation of constructs and measures in terms of the formal hypotheses derived in theory. ... it entails investigating both the theoretical relationship between different constructs and the empirical relationship between measures of those different constructs" (Peter 1981, p. 135).

\section{Sampling Strategy}

Each bank was asked to choose two financial service innovation projects, one success and one failure. The chosen service projects had to be launched not more than two years ago in order to 
prevent recall decay bias. Moreover, the projects had to be developed internally and should involve personnel from different functional units. The appropriate respondents were selected according to their involvement in the development process of the new financial service project.

During the first phase of the data collection process 124 Belgian banks, all listed in the directory of the Belgian Association of Banks, were contacted by phone. However, 41 banks had to be excluded from the sample as they were not active in developing new services. These banks were often small subsidiaries of foreign banks so that their scale of operations was either too limited or they were only engaged in selling and administration. Another six banks were not considered in the sample because of bankruptcy or take-over.

In the second phase, we administered the set of questionnaires to the remaining sample of 77 financial institutions. In total, 36 banks returned 65 valid questionnaires including 37 commercially successful projects and 28 commercially unsuccessful projects. Convincing banks to provide information on financial service innovations that were failures is more difficult than getting information on successful projects. This bias has often been observed in cross-sectional surveys on financial service innovation (de Brentani, 1989; 1991; 1993; 1995; Cooper and de Brentani, 1991; Easingwood and Storey, 1993; 1994) and within product innovation research (e.g. Cooper, 1979). It gives the impression that organizations are less eager and often quite unwilling to admit the existence of failure due to the potential 'loss of face'.

We have achieved a response rate of $42 \%$ as we had sent 154 questionnaires of which 65 were returned due to several strategies to achieve a high response rate. The mailing included an introductory letter, a fax document that should facilitate the identification of the respondents and the corresponding project and two questionnaires with accompanying letters for these respondents. We guaranteed anonymity and confidentiality. Moreover, we told the respondents that they would benefit from participation. We organized four follow-up rounds by phone with two weeks in-between the follow-up sessions. One month after the last follow-up round, a final reminder letter with questionnaires was sent to the respondents. Finally, the participating banks were invited to a presentation and a feedback session and received a summary of the findings.

\section{Research Findings}

\section{Data Screening}

Since all our propositions are directional, we used one-tailed significance tests. Additionally, we decided to use an $\alpha$-level of 0.10 to determine significance as our sample has a limited size $(\mathrm{N}=65)$. This significance level allowed as minimizing Type II errors (Cook and Campbell, 1979; Hays, 1986; Henkel, 1976). Before we started the data analysis, we screened all variables carefully to validate that the variables fulfill the assumptions about normality, linearity, interdependence and homogeneity of variance (Tabachnick and Fidell, 1979).

We checked for univariate outliers among the continuous variables by inspecting the standardized scores (measures with a $\mathrm{z}$-score in excess of \pm 3 ) and the normal probability plots. Through computation of Mahalanobis' distance, multivariate outliers were identified. As we already have a small sample size, we decided not to delete these cases, but to reduce their 
influence by assigning them a value that was one unit larger (or one unit smaller) than the next extreme score in the distribution that was not an outlier (Tabachnick and Fidell, 1989, p. 70).

\section{Results}

We want to investigate the role of learning as a mediator (Baron and Kenny, 1986) in our causal framework concerning the nature of the link with learning antecedents and the impact of learning on performance. Learning is a mediator variable as its role changes from a dependent variable (in its relationship with organizational antecedents and the nature of communication) to an independent variable (in its contribution to performance).

\section{Learning Antecedents: The Nature of Communication}

Table 1 shows the zero-order correlation coefficients for learning, the nature of communication and the quality of the new service development process. Proposition 1 and 2 are supported by our data. Both types of communication significantly relate to the level of project learning. The level of innovative communication relates positively to the level of project learning $(\mathrm{r}=.38, \mathrm{p}<.001)$. Furthermore, the level of coordinative communication relates positively to the level of project learning $(\mathrm{r}=.28, \mathrm{p}<.05)$.

Take in table 1

\section{The Moderating Impact of the New Service Innovation Process}

Hierarchical regression analysis (Pedhazur, 1982) was performed to examine the moderating effect of the quality of the new service innovation process stages on the relationship between the nature of communication and the level of project learning. The results are presented in Table 2 . We want to investigate whether the interaction term (innovative communication*quality of the planning stage) significantly adds $\left(=\mathrm{R}^{2} \Delta\right)$ to the explanation of the variance in the dependent variable (project learning). Proposition 3 [a] is supported by the analysis. Thus, the quality of the planning activities during the new service innovation process positively moderates the relationship between innovative communication and the level of project learning.

Proposition 3[b] is not supported by our data. We did not find any significant interaction effects between coordinative communication and the quality of the development and the launch stage. Although the correlation coefficients show clear interrelations between coordinative communication and the development and the launch stage, the hierarchical regression analysis does not provide support for a positive moderating effect. We just know that innovative communication is very important during the planning stage for project learning to take place, however, we cannot determine how coordinative and innovative communication should be balanced. Previous research has shown that there exists a trade-off between coordinative and innovative communication (Hauptman, 1986; Greenbaum, 1974; Souder and Moenaert, 1992; Edvardsson, Haglund and Mattsson, 1995). Thus, an organization has to find the right balance between these two types of communication. It could be possible that a constant amount of coordinative communication is needed for the existence of innovative communication. Our research setting does not allow us to confirm this assumption, as a longitudinal research design would be needed to investigate the flow of different types of communication in time. Another 
explanation for the absence of a significant interaction between the quality of the development and the launch stage and coordinative communication may be the simple fact that coordinative communication is a prerequisite for a successful innovation process but it does not contribute to project learning as such. Coordinative communication is needed for the cooperation of different functional units but it does not seem to affect the learning between these various units. Coordination may be required for routine tasks (Souder and Moenaert, 1992) in order to implement the ideas developed in the planning stage. Thus, coordinative communication is essential for the new service innovation process but it does not significantly add to the level of project learning.

Take in table 2

\section{Learning Antecedents: Organizational Design}

Table 3 provides the Pearson zero-order correlation coefficients for learning and the organizational antecedents: top management support, cross-functional interface, organizational diversity and participative decision-making. Proposition 4 to 7 can be supported by our correlation analyses. The organizational antecedents all show a significant positive relationship with project learning. The level of project learning relates positively to the level of top management support $(\mathrm{r}=.50, \mathrm{p}<.001)$. The level of project learning relates positively to the level of cross-functional interfaces $(\mathrm{r}=.260, \mathrm{p}<.05)$. Additionally, The level of project learning relates positively to the level of organizational diversity $(r=.319, p<.01)$. Furthermore, the level of project learning relates positively to the level of participative decision-making $(\mathrm{r}=.338, \mathrm{p}<$ $.01)$.

Take in table 3

\section{Learning Consequences: New Financial Service Performance}

Table 4 provides the Pearson zero-order correlation coefficients for learning and the performance variables. Proposition 8 till 12 are supported by our data. All performance measures are significantly related to project learning. The corporate reputation of the innovating financial institution relates positively to the level of project learning $(\mathrm{r}=.52, \mathrm{p}<0.001)$. The competitive position of the innovating financial institution relates positively to the level of project learning $(\mathrm{r}=.61, \mathrm{p}<0.001)$. Furthermore, the cost position of the innovating financial institution relates positively to the level of project learning $(\mathrm{r}=.55, \mathrm{p}<0.001)$. The level of cross-selling of the innovating financial institution relates positively to the level of project learning $(r=.45, p<$ 0.001). The increase in service delivery capacity of the financial service innovation relates positively to the level of project learning $(r=.73, \mathrm{p}<0.001)$.

\section{Take in table 4}

\section{Project Learning as a Mediator}

Our data also demonstrate the mediating role of project learning between (1) the nature of communication and the performance outcomes on the one hand and (2) organizational 
antecedents and the performance outcomes on the other hand. In other words, they provide support for the proposition that the effects of the nature of communication and organizational antecedents on performance outcome is not a direct one, but one that is mediated by project learning (Baron and Kenny, 1986). As all our hypotheses are stated directional testing the mediation should be done using bivariate analyses. As the beta coefficient of a simple regression is equal to Pearson's correlation coefficient (Pedhazur, 1982), we used bivariate correlations and computed the partial correlations between the independent variables (the nature of communication and organizational antecedents) and the dependent variables (performance outcomes) and we controlled for the mediating variable (project learning). Thus, we corroborated the latter analysis with the regression method suggested by Baron and Kenny (1986) in order to test mediation. As table 5 illustrates, significant positive correlations exist between the nature of communication and performance outcomes. Similarly, there are significant positive correlations between organizational antecedents and performance outcomes. We postulate that these significant correlations result mainly from the mediating role of project learning. Indeed, this assertion was supported after calculating the partial correlation between the nature of communication and the performance measures controlling for the level of project learning. In seven of ten cases correlation between the nature of communication and the performance outcomes were no longer significant. Nevertheless, in the other three cases there was a reduction in the Pearson correlation coefficient when controlling for project learning indicating the right direction and thereby supporting a mediating relationship. The mediating relationship is also supported when considering the correlations and the partial correlations between the organizational antecedents and the performance outcomes. In twelve out of twenty cases the correlations are no longer significant. Again, in the other eight cases there is a clear decrease in the correlation coefficient as well as in the level of significance. All partial correlations are shown in table 6.

Take in table 5 and 6

\section{Discussion}

\section{Managerial Implications}

Project learning involves information processing activities that build up a knowledge base. Organizations that want to encourage the development of a knowledge base need to pay attention to the nature of communication and the organizational design settings. Innovative communication is particularly important during the planning stage of the innovation process when creativity must be stimulated. Thus, innovation managers within banks should manage organizational learning during the innovation process. Especially during the planning stage innovative communication plays a crucial role in steering learning. Moreover, the quality of the planning stage of the new service innovation process is of major importance as it fosters the impact of innovative communication. Managers should emphasize creative thinking and idea exchange during the planning stage as project learning is at its highest level. Thus, innovative communication should especially be stimulated during the planning stage as it may have an important leveraging effect on project learning. 
Furthermore, managers must create an organizational setting that facilitates and encourages learning behavior. A major prerequisite is that top management supports project learning behavior within the innovation project. As top managers give future directions, they should stimulate the exchange of ideas. They should show that they are interested in the project and that they will support it via their decisions for resources and investments. Employees should be allowed to make mistakes as punishment might impede learning initiatives (Schein, 1993). Some researchers have found that the existence of a medium level of organizational slack (Drew, 1994; Nohria and Gulati, 1996), where people are allowed to invest their time in 'blue sky' projects and experimentation, leads to creativity and learning. An organization should establish a learning environment by offering opportunities for training, giving support and encouragement, and rewarding for efforts in the right direction and for creative thinking as these initiatives are powerful tools for encouraging the transfer of knowledge (Garvin, 1993; Leonard-Barton, 1992). Job descriptions and rewards could be linked to the learning behavior of an employee by incorporating learning in the yearly review about an employee's performance. Moreover, a good organizational learning environment is a sustainable competitive advantage that is hard to imitate by competitors.

Additionally, banks should stimulate cross-functional interfaces as these encourage the exchange of ideas, and hence learning. Employees have a better insight in the activities of the whole company and do not only fulfill their part of the job. Therefore, cross-functional cooperation should be supported via regular cross-functional meetings. Additionally, project teams should involve experts from different departments so that knowledge sharing can happen. Organizational diversity is another important factor as various specialists can exchange their expertise. Thus, when recruiting personnel, managers should select employees with different backgrounds and skills so that other employees can profit from their knowledge. Involving people from different departments in one project opens up boundaries that lead to a stimulating working atmosphere.

Learning is a social process (Van de Ven, 1986; Bouwen and Fry, 1991; Bartlett and Ghoshal, 1998) and brings employees into contact with each other. Consequently, they can develop an organizational identity through shared values and meanings that will in turn diminish misunderstandings. Participative decision-making also stimulates learning behavior that is crucial for the motivation of the employees (Conger and Kanungo, 1988; Spreitzer, 1995). Through participating, they can achieve self-fulfillment and are more satisfied. Decisions that are worked out together are easier implemented as employees support the decision. Thus, the employees' motivation to engage in information processing activities is enlarged. These activities are essential in an innovative setting and service innovations are indispensable in the dynamic financial service environment.

Project learning is fundamental as it enhances organizational performance. It has been shown that new service development can be assessed using all kinds of performance measures. Managers should not focus too much on one performance criterion but rather should consider several performance appraisals in the investigation of new service development (Johne and Storey, 1998). We presented several performance measures that are important in the assessment of new service success (Easingwood and Percival, 1990). We considered performance measures on the project level and on the level of the financial institution itself. 
Learning oriented innovation management may improve the corporate reputation, which is an important factor in the financial service industry where customer decision-making depends to a large extent on the corporate image of an institution. Moreover, having a reputation for being innovative facilitates the introduction of radical innovations, as consumers are more eager to accept such introductions (Johne and Storey, 1998). The competitive position is also augmented which is indispensable in the highly dynamic financial service industry. Thus, through learning the organization is able to maintain competitiveness also in unstable environments and is prepared to adapt to new eroding circumstances in a fast and effective manner. Furthermore, the cost position of an organization is improved as learning leads to dynamic efficiency that can be exploited especially during information acquisition. Lower costs are always an important issue as the savings can be invested in other projects and return on investment is higher. Moreover, the institution is able to catch new customers that could become customers of their exiting products leading to an increase in turnover. The organization acquires and disseminates new knowledge about customers and competitors through cross-selling activities that can be incorporated in existing services. Additionally, the company can increase its service delivery capacity, which expands the abilities and competences of the employees. Thus, the organization invests in its future position. An increased service delivery capacity also results in an enhancement of customer satisfaction. Customer satisfaction is a prerequisite for a market-oriented organization that wants to sustain in the competitive environment. Consequently, learning is crucial in its contribution to organizational performance.

\section{Conclusion and Suggestions for Future Research}

Our study demonstrates the crucial relationship between learning and project performance as well as organizational performance. As learning during innovation comprises a process, future research should consider a longitudinal study that could provide more insight into the different stages and its interaction with the nature of communication necessary to ensure continuous learning. The longitudinal design could also pay attention to a possible iterative relationship between coordinative communication and project learning. Project learning may have a positive effect on coordinative communication in subsequent new service development projects.

Moreover, the focus of our study with respect to the nature of communication is limited to internal communication. However, external communication is very important for project learning because through boundary spanning activities with external stakeholders the organization can acquire important information that does not exist within the organization. Thus, a future study should consider the impact of external communication on project learning during new service development.

The organizational context is an important determinant of the level of project learning. A supportive, harmonious, and participative climate offers the best conditions for learning to take place. In our research we modeled both communication and organizational design as antecedents of learning. Future research should probe more deeply into the relationship between the nature of communication and organizational design. Some design contingencies may be more favorable to innovative than to coordinative communication.

This brings us to our last reflection. This study in fact limits communication to one typology. However, the digital economy will create an entirely new communication platform. The new 
developments in the electronic environment cause many technological innovations that might have an impact on the new financial service innovation process. E-commerce opportunities and better internal systems (software and hardware) might change the process. It offers opportunities for better communication via e-mail and sharing material online (e.g. Microsoft Netmeeting) that facilitates information exchange. In contrast, it may be counterproductive to learning as a social process as employees do not communicate personally anymore but only via technical means. Managers often focus on speed to market as a strategic priority. Re-engineering principles with the focus of establishing an organizational culture and structure that encourage team working and empowerment can result in an improvement in time-to-market (Drew, 1994). Consequently, future research may investigate the impact of the upcoming digital environment on the learning process. 


\section{References}

Argyris, C., and Schön, D. A.: Organizational Learning: A Theory of Action Perspective, Reading, MA: Addison-Wesley Publishing Co. 1978.

Baker, William E., and Sinkula, James M., The Synergistic Effect of Market Orientation and Learning Orientation on Organizational Performance. Journal of the Academy of Management Science, 27, (1999): 295-308.

Baron, Reuben M., and Kenny, David A., The Moderator-Mediator Variable Distinction in Social Psychological Research: Conceptual, Strategic and Statistical Considerations. Journal of Personality and Social Psychology, 51, (1986): 1173-1182.

Bartlett, Christopher A., and Ghoshal, Sumantra, Beyond Strategic Planning to Organizational Learning: Lifeblood of the Individualized Corporation. Strategy and Leadership, 23, (1998): 34-39.

Bouwen, Rene and Fry, Ronald, Organizational Innovation and Learning: Four Patterns of Dialog between the Dominant Logic and the New Logic. International Studies of Management \& Organization, 21, (Winter 1991): 37-48.

Campbell, D. T., and Stanley, J. C.: Experimental and Quasi-experimental Designs for Research, Dallas, Houghton Mifflin Company Boston. 1963.

Carroll, Glenn R., and Hannan, Michael T., Why Corporate Demography Matters: Policy Implications of Organizational Diversity. California Management Review, 42, (Spring 2000): 148-163.

Churchill, Gilbert A. Jr., and Peter, Paul J., Research Design Effects on the Reliability of Rating Scales: A Meta-Analysis. Journal of Marketing Research, XXI, (Nov 1994): 360-375.

Churchill, Gilbert A. Jr., A Paradigm for Developing Better Measures of Marketing Constructs. Journal of Marketing Research, XVI, (Feb 1979): 64-73.

Cohen, Wesley M., and Levinthal, Daniel A., Absorptive Capacity: A New Perspective on Learning and Innovation. Administrative Science Quarterly, 35, (March 1990): 128-152.

Collis, David, Organizational Capability as a Source of Profit, in Organizational Learning and Competitive Advantage, Bertrand Moingeon and Amy Edmondson, eds., Sage Publications, London. 1996, pp. 139-163.

Conger, Jay A. and Kanungo, Rabindra N., The Empowerment Process: Integrating Theory and Practice. Academy of Management Review, 13, (1988): 471-482.

Cook, T. D., and Campbell, D. T.: Quasi-Experimentation: Design and Analysis Issues for Field Settings, Houghton Mifflin Company, Boston. 1979.

Cooper, Robert G., The Dimensions of Industrial New Product Success and Failure. Journal of Marketing, Vol. 43, (Summer 1979): 93-103.

Cooper, Robert G., and de Brentani, Ulrike, New Industrial Financial Services: What Distinguishes the Winners. Journal of Product Innovation Management, Vol. 8, (1991): 7590.

Cooper, Robert G., and de Brentani, Ulrike, Criteria for Screening New Industrial Products. Industrial Marketing Management, 13, (1984): 149-156.

Cooper, Robert G., and Kleinschmidt, Elko J., An Investigation into the New Product Process: Steps, Deficiencies and Impact. Journal of Product Innovation Management, 3, (1986): 7185.

Cooper, Robert G., Easingwood, Christopher J., Edgett, Scott, Kleinschmidt, Elko J., and Storey, Chris, What Distinguishes the Top Performing New Products in Financial Services. Journal of Product Innovation Management, 11, (1994): 281-299. 
Cronbach, Lee J., and Meehl, Paul E., Construct Validity in Psychological Tests, in Problems in Human Assessment, Jackson and Messic, eds., McGraw-Hill, New York. 1967, pp. 57-77.

Cross, Rob, and Baird Lloyd, Technology is not Enough: Improving Performance by Building Organizational Memory. Sloan Management Review, 41, (Spring 2000): 69-78.

Crossan, Mary M., Lane, Henry W., and White, Roderick E., An Organizational Learning Framework: From Intuition to Institution. Academy of Management Review, 24, (Jul 1999): 522-537.

Daft, Richard L., and Weick, Karl E., Towards a Model of Organizations as Interpretation Systems. Academy of Management Review, 9(2), (1984): 284-295.

Day, George S., The Capabilities of Market-Driven Organizations. Journal of Marketing, 58, (October 1994): 37-52.

de Brentani, Ulrike, Success Factors in Developing New Business Services. European Journal of Marketing, Vol. 24, No. 2., (1991): 33-59.

de Brentani, Ulrike, New Industrial Service Development: Scenarios for Success and Failure. Journal of Business Research, 32, (1995): 93-103.

de Brentani, Ulrike, Success and Failure in New Industrial Services. Journal of Product Innovation Management, 6, (1989): 239-258.

de Brentani, Ulrike, The New Product Process in Financial Services: Strategy for Success. International Journal of Bank Marketing, 11, (1993): 15-21.

DiBella, Anthony J., Developing Learning Organizations: A Matter of Perspective. Academy of Management Journal, Best Papers Proceedings 1995, (1995): 287-295.

Drew, S.: Business Re-engineering in Financial Services, Pitman Publishing, London. 1994.

Duncan, Tom, and Moriarty, Sandra E., A Communication-Based Marketing Model for Managing Relationships. Journal of Marketing, 62, (Apr 1998): 1-13.

Duncan, Robert, and Weiss, Andrew, Organizational Learning: Implications for Organizational Design. Research in Organizational Behavior, 1, (1979): 75-123.

Dunn, William N., Conceptualizing Knowledge Use, in Knowledge Generation, Exchange and Utilization, G.M. Beal, W. Dissanayake, and S. Konoshima, eds., Boulder, CO: Westview Press. 1986.

Easingwood, Christopher J., and Percival, John, Evaluation of New Financial Services. International Journal of Bank Marketing, 8, (1990): 3-8.

Easingwood, Christopher J., and Storey Chris, Marketplace Success Factors for New Financial Services. The Journal of Services Marketing, Vol. 7, No 1, (1993): 41-54.

Easingwood, Christopher J., and Storey, Chris, Success Factors for New Consumer Financial Services. International Journal of Bank Marketing, 9, (1991): 3-10.

Easterby-Smith, Mark, Disciplines of Organizational Learning: Contributions and Critiques. Human Relations, 50, (Sep 1997): 1085-1113.

Edgett Scott, and Parkinson, Steven, The Development of New Financial Services: Identifying Determinants of Success and Failures. International Journal of Service Industry Management, 5, (1994): 24-38.

Edgett, Scott, and Jones, Steve, New Product Development in the Financial Service Industry: A Case Study. Journal of Marketing Management, 7, (1991): 271-284.

Edgett, Scott, The Traits of Successful New Service Development. Journal of Services Marketing, 8, (1994): 40-49.

Edmondson, Amy, Psychological Safety and Learning Behavior in Work Teams. Administrative Science Quarterly, 44, (June 1999): 350-383. 
Edvardsson, Bo, Haglund, Lars, and Mattsson, Jan, Analysis, Planning, Improvisation and Control in the Development of New Services. International Journal of Service Industry Management, 6, (1995): 24-35.

Ennew, Christine T., and Wright, Mike, Retail Banks and Organisational Change: Evidence from the UK. International Journal of Bank Marketing, 8, (1990): 4-9.

Garvin, David A., Building a Learning Organization. Harvard Business Review, 71, (1993): 7891.

Ghemawat, Pankaj, and Ricard I Costa, Joan E., The Organizational Tension between Static and Dynamic Efficiency. Strategic Management Journal, 14, (1993): pp. 59-73.

Gibson, J. L., Ivancevich, J. M., and Donnelly, J. H. Jr.: Organizations: Behavior, Structure and Processes, Sixth Edition, Business Pubilcations, Inc, Plano. 1988.

Greenbaum, Howard H., The Audit of Organizational Communication. Academy of Management Journal, 17, (Dec 1974): 739-754.

Grönroos, C.: Service Management and Marketing: Managing the Moments of Truth in Service Competition, Lexington Books/Maxwell Macmillan International Editions, 1990.

Gummesson, Evert, The New Marketing - Developing Long-term Interactive Relationships. Long Range Planning, 20, (1987): 10-20.

Hauptman, Oscar, Influence of Task Type on the Relationship Between Communication and Performance: the Case of Software Development. R\&D Management, 16, (1986): 127-139.

Hays, W. L.: Statistics, Fourth Edition, Holt, Rinehart and Winston, New York. 1986.

Helfat, Constance E., Evolutionary Trajectories in Petroleum Firm R\&D. Management Science, 40(12), (December 1994): 1720-1747.

Henkel, R. E.: Tests of Significance, Sage, Beverly Hills. 1976.

Hine, Michael J., and Goul, Michael, The Design, Development, and Validation of a KnowledgeBased Organizational Support System. Journal of Management Information Systems, 15, (Fall 1998): 119-153.

Huber, George P., Organizational Learning: The Contributing Process and the Literatures. Organization Science, 2, (Feb 1991): 88-115.

Hult, G. Tomas M. and Ferrell, O. C., A Global Learning Organization Structure and Market Information Processing. Journal of Business Research, 40, (1997a): 155-166.

Hult, G. Tomas M. and Ferrell, O. C., Global Learning Capacity in Purchasing: Construct and Measurement. Journal of Business Research, 40, (1997b): 99-111.

Hult, G. Tomas M., Managing the International Strategic Sourcing Process as a Market-Driven Organizational Learning System. Decision Sciences, 29, (1998): 193-216.

Hurley, Robert F., and Hult, G. Tomas H., Innovation, Market Orientation, and Organizational Learning: An Integration and Empirical Examination. Journal of Marketing, 62, (July 1998): 42-54.

Jaarvenpaa, Sirkka L., and Ives, Blake, The Global Network Organization of the Future: Information Management Opportunities and Challenges. Journal of Management Information Systems, 10, (Spring 1994): 25-57.

Jaworski, Bernard J., and Kohli, Ajay K., Market Orientation: Antecedents and Consequences. Journal of Marketing, 57, (July 1993): 53-70.

Johne, Axel, and Harborne, P., How Large Commercial Banks Manage Product Innovation. International Journal of Bank Marketing, 3, (1985): 54-70.

Johne, Axel, and Storey, Chris, New Service Development: A Review of the Literature and Annotated Bibliography. European Journal of Marketing, 32, (1998): 184-251. 
Judd, C. M., Smith, E. R., and Kidder, L. H.: Research Methods in Social Relations, Sixth Edition, Forth Worth: Harcourt Brace Jovanovich College Publishers. 1991.

Kim, Daniel H., The Link between Individual and Organizational Learning. Sloan Management Review, 35, (1993), 37-50.

Kogut, Bruce, and Zander, U., Knowledge of the Firm, Combinative Capabilities, and The Replication of Technology. Organization Science, 3(3), (1992): 383-397.

Lant, Theresa K., and Mezias, Stephen J., An Organizational Learning Model of Convergence and Reorientation. Organization Science, 3(1), (February 1992): 47-71.

Lei, David, Slocum, John W., and Pitts, Robert A., Designing Organizations for Competitive Advantage: The Power of Unlearning and Learning. Organizational Dynamics, 27, (Winter1999): 24-38.

Leonard-Barton, Dorothy, Core Capabilities and Core Rigidities: A Paradox in Managing New Product Development. Strategic Management Journal, 13, (1992): pp. 111-125.

Levitt, Barbara, and March, James G., Organizational Learning. Annual Review of Sociology, 14, (1988): 319-340.

Lievens, Annouk, and Moenaert, Rudy K., New Service Teams as Information Processing Systems: Reducing Innovative Uncertainty. Journal of Service Research, 3, (Aug 2000a): 46-65.

Lievens, Annouk, and Moenaert, Rudy K., Communication flows during Financial Service Innovation. European Journal of Marketing, 34, (2000b).

Lievens, Annouk, de Ruyter, Ko, and Lemmink, Jos, Learning during New Banking Service Development: A Communication Network Approach to Marketing Departments. Journal of Service Research, 2, (Nov 1999): 145-163.

Lievens, A., Moenaert, Rudy K., and S'Jegers, Rosette, Linking Communication to Innovation Success in the Financial Services Industry: A Case Study Analysis. International Journal of Service Industry Management, 10, (1999): 23-47.

Mahajan, Jayashree, Vakharia, Asoo J., Paul, Pallab, and Chase, Richard B., An Exploratory Investigation of the Interdependence Between Marketing and Operations Functions in Service Firms. International Journal of Research in Marketing, 11, (Jan 1994): 1-15.

McGill, Michael E., Slocum, John W. Jr., and Lei, David, Management Practices in Learning Organizations. Organizational Dynamics, 21, (Summer 1992): 5-17.

Moenaert, Rudy K., De Meyer, Arnoud, Souder, William E., and Deschoolmeester, Dirk, R\&D/Marketing Communication during the Fuzzy Front-end. IEEE Transactions on Engineering Management, 42, (Aug 1995): 243-258.

Moenaert, Rudy K., Deschoolmeester, Dirk, de Meyer, Arnoud, and Souder William E., Information Styles of Marketing and R\&D Personnel during Technological Product Innovation Products. R\&D Management, 22, (Jan 1992): 21-37.

Moorman, Christine, Organizational Market Information Processes: Cultural Antecedents and New Product Outcomes. Journal of Marketing Research, 32, (August 1995): 318-335.

Morgan, Robert E., Cronin, Eileen, and Severn, Maer, Innovation in Banking: New Structures and Systems. Long Range Planning, 28, (1995): 91-100.

Nevis, Edwin C., DiBella, Anthony J., and Gould, Janet M., Understanding Organizations as Learning Systems. Sloan Management Review, Vol. 73, (Winter 1995): 73-85.

Nohria, Nitin, and Gulati, Ranjay, Is Slack Good or Bad for Innovation?. Academy of Management Journal, 39, (1996): 1245-1264.

Nunnally, J. C., and Bernstein, I. H.: Psychometric Theory, Third Edition, McGraw-Hill Series. 1994. 
Nunnally, J. C.: Psychometric Theory, McGraw-Hill, New York. 1967

Pedhazur, E. J.: Multiple Regression in Behavioral Research, Holt, Rinehart, and Winston, Fort Worth. 1982.

Peter, J. Paul, Construct Validity: A Review of Basic Issues and Marketing Practices. Journal of Marketing Research, XVIII, (May 1981): 133-145.

Peter, J. Paul, Reliability: A Review of Psychometric Basics and Recent Marketing Practices. Journal of Marketing Research, XVI, (Feb 1979): 6-17.

Peter, J. Paul and Churchill, Gilbert A. Jr., Relationships Among Research Design Choices and Psychometric Properties of Rating Scales: A Meta-Analysis. Journal of Marketing Research, XXIII, (Feb 1986): 1-10.

Pinto, Mary B., Pinto, Jeffrey K., and Prescott, John E., Antecedents and Consequences of Project Team Cross-functional Cooperation. Management Science, 39, (Oct 1993): 12811297.

Prahalad, C. K., and Hamel, Gary, The Core Competence of the Corporation. Harvard Business Review, 68, (May-June 1990): 79-91.

Ribbens, Barbara A., Organizational Learning Styles: Categorizing Strategic Predispositions from Learning. International Journal of Organizational Analysis, 5, (Jan 1997): 59-73.

Rogers, E. M. and Agarwala-Rogers, R.: Communication in Organizations, The Free Press, Collier Macmillan Publishers, London. 1976.

Rogers, E. M., and Shoemaker, E. F.: Communication of Innovations: A Cross-Cultural Approach, Second Edition, The Free Press - Division of Macmillan Publishing Co., Inc., New York. 1971.

Scarborough, Harry, and Lannon, Ronnie, The Successful Exploitation of New Technology in Banking. Journal of General Management, 13, (Spring 1988): 38-51.

Schein, Edgar H., How Can Organizations Learn Faster? The Challenge of Entering the Green Room. Sloan Management Review, 34, (Winter 1993): 85-95.

Senge, P. M.: The Fifth Discipline: The Art and Practice of the Learning Organization, Currency Doubleday, New York. 1990.

Seufert, Andreas, von Krogh, Georg and Bach, Andrea, Towards Knowledge Management. Journal of Knowledge Management, 3, Issue 3, (1999).

Shivastrava, Paul, A Typology of Organizational Learning Systems. Journal of Management Studies, 20(1), (1983): 7-28.

Sinkula, James M., Baker, William E., and Noordewier, Thomas, Framework for Market-based Organizational Learning: Linking Values, Knowledge and Behavior. Academy of Management Science, 25, (Fall 1997): 305-318.

Sinkula, James M., Market Information Processing and Organizational Learning. Journal of Marketing, 58, (January 1994): 35-45.

Slater, Stanley F., and. Narver, John C., Market Oriented Isn't Enough: Build a Learning Organization, in Market Orientation, Brynjulf Tellefsen, ed., Fagbokforlaget, BergenSandviken.1995a, pp. 223-250.

Slater, Stanley F., and Narver, John C., Market Orientation and the Learning Organization. Journal of Marketing, 59, (July 1995b): 63-74.

Souder, William E., and Moenaert, Rudy K., Integrating Marketing and R\&D Project Personnel Within Innovation Projects: An Information Uncertainty Model. Journal of Management Studies, 29, (Jul 1992): 485-511.

Spreitzer, Gretchen, Psychological Empowerment in the Workplace: Dimensions, Measurement, and Validation. Academy of Management Journal, 38, (1995): 1442-1465. 
Storey, Chris, and Easingwood, Christopher J., The Impact of the New Product Development Project on the Success of New Financial Services. The Service Industries Journal, 13, (Jul 1993): 40-48.

Swan, Jacky, Newell, Sue, Scarborough, Harry, and Hislop, Donald, Knowledge Management and Innovation: Networks and Networking. Journal of Knowledge Management, 3, (1999): $262-275$.

Tabachnick, B. G., and Fidell, L. S.: Using Multivariate Statistics, Second edition, HarperCollins Publishers. 1989.

Thwaites, Des, Organizational Influences on the New Product Development Process in Financial Services. Journal of Product Innovation Management, 9, (1992): 303-313.

Tsang, Eric W. K., Organizational Learning and the Learning Organization: A Dichotomy between Descriptive and Prescriptive Research. Human Relations, 50, (Jan 1997): 73-89.

Tucker, Mary L., Meyer, Gary D., and Westerman, J. W., Organizational Communications: Development of Internal Strategic Competitive Advantage. Journal of Business Communication, 33, (Jan 1996): 51-62.

Van de Ven, Andrew H., Central Problems in the Management of Innovation. Management Science, 32, (May 1986): 590-607. 


\section{Appendix : Individual items used to measure the constructs with reliability estimates}

\section{Project Learning (Cronbach $\alpha=.87)$}

Following the case study research findings an own scale design was constructed for learning effects. Project teams are seen primarily as information processing systems. In line with our definition on communication and communication effectiveness, we consider the effect of communication to be cognitive, equivalent to the creation of a knowledge base. As a result project teams gain knowledge and consequently learn (e.g., Levitt and March, 1988; Leonard-Barton, 1992; Kim, 1993 ) as they exchange information. The following scale instruction was provided on the questionnaire:

Shown below are a number of statements and questions. Along with each statement, you will find a scale. Please indicate how strongly you agree with each of the following statements, relative to the presently discussed project. Circle the scale value that best reflects your opinion. $(1=$ strongly disagree to $5=$ strongly agree $)$

1. Our experience and learning in this project proved to be essential for the successful creation and completion of subsequent projects.

2. The knowledge acquired during the innovation process of this project served as an essential input for other new service developments.

3. The development of this new financial service created a general development expertise that eased the development and introduction of subsequent new services.

4. The expertise of developing and launching this new financial service lead to an enhanced know-how for future innovation projects.

5. Through the development and launch of this new service, project members learned a lot on new financial service innovation.

\section{The nature of communication}

In order to specify the nature of the information that is transferred during financial service innovation process, we have used the communication typology proposed by Hauptman (1986): coordinative and innovative information. Hauptman (1986) examined this communication typology as a mediator between task type and performance in the case of software development. The duality between coordination and innovation requirements of the task was proposed as a predictor of optimal communication patterns and was linked to the structure, stability and newness of the technology involved in the task. Both types of information give a clear picture of the kind of information that is exchanged during the innovation process. Innovative communication comprises creativity in problem solving and new idea processing, and an adaptation to change. Coordinative communication relates to the assignment of instructions to project members so that they can execute their jobs (Souder and Moenaert, 1992) and includes controls, orders, direction and feedback between subordinates and superiors in task-related activities (Greenbaum, 1974). The following scale instruction was provided on the questionnaire: Shown below are a number of statements concerning the communication during the innovation process. Under each statement, you will find a numbered scale, and an explanation of the appropriate meaning of the numbers. Please rate each statement according to the degree the statement describes your opinion for this project. Draw a circle around the number that best reflects your choice.

\section{Innovative Communication (Cronbach $\alpha=.56)$}

1. Information concerning the technological requirements was widely available during new service development.

2. During the innovation process of this project, how well were project members informed and updated concerning commercial information (customer, competition)?

3. To what extent did information from other departments provide you and other project members in your department with more insight and understanding to solve specific problems.

4. Less structured information is also exchanged during new service development in order to induce the innovativeness of the project, in which new information is generated or problems are solved in a creative way. How frequently was information transferred that was helpful in solving work-related problems?

\section{Coordinative Communication (Cronbach $\alpha=.64)$}

1. During the development and launch preparation of this project, how good was the project members' insight of what everybody else involved with this project was actually doing?

2. Project members within other departments all performed specific activities during the innovation process of this project. How much of all the activities your colleague-members did during new service development was known by you and members of your department involved in this project?

3. During the innovation process of this project, how well were project members informed and updated concerning the time restrictions and completion dates of the activities to be undertaken?

4. In order to ensure that all project members work together in an integrated and coordinated manner, information has to be transferred concerning instructions/rules and procedures necessary for task execution. How frequently was information transferred from or to your department/team in order to coordinate the work of your unit. 


\section{The performance of the new financial service}

New financial service performance has been assessed by several measures. This is in line with the generally held view that success is a multidimensional construct (Craig and Hart, 1992; Griffin and Page, 1993; Montoya-Weiss and Calantone, 1994). These measures were selected on the basis of (1) internal consistency (i.e., if the item pools were generated on the basis of existing measures) and (2) case study research. The following scale instruction was provided on the questionnaire: Shown below are a number of statements and questions. Along with each statement, you will find a scale. Please indicate how strongly you agree with each of the following statements, relative to the presently discussed project. Circle the scale value that best reflects your opinion. $(1=$ strongly disagree to $5=$ strongly agree $)$

\section{Cross selling (Cronbach $\alpha=.76)$}

Cross selling has also been proposed (Easingwood 1991, de Brentani 1989) as an important non-financial performance measure. This construct was measured through of a three-item scale that indicated the extent to which the new service enhanced the profitability of the existing products of the bank.

1. This new service boosted sales or market share of the existing services.

2. New customers, acquired through this new service, became user of existing services.

3. This new service enhanced sales and profitability of other services offered by our organization.

\section{Corporate reputation $($ Cronbach $\alpha=.84)$}

Corporate reputation was included, and measured by means of a two-item scale assessing the impact of the new financial service on the image of the bank (Easingwood and Storey 1993).

1. The introduction of this new service has strengthened the company's reputation.

2. This new service had a positive impact on the reputation of our company.

\section{Increasing service delivery capacity (Cronbach $\alpha=$.86)}

Increasing service delivery capacity has also been proposed as an important indirect performance measure of banks (Easingwood, 1991) and was initially measured by means of a two-item scale that reflected the degree to which the new service would improve new service development capability.

1. This innovation is a platform that will ease introduction of subsequent new products.

2. The development of this new financial service improved the new service development capability of our organization.

3. The systems (hardware, software, delivery systems) developed to launch this new financial service provided a basis for a better introduction of services in the future.

4. This new service increased the general service delivery capability of the organization.

\section{Competitive position (Cronbach $\alpha=.84$ )}

The measure of competitive position as a performance measure for new financial service projects was based on the operationalization of de Brentani [1989, 1991] and Storey [1993]. This construct was measured by a three-item scale, assessing the contribution of the new service in strengthening the unique benefit of the new service (and hence the competitive advantage of the bank).

1. This new service provided the organization with an important competitive advantage.

2. This new service had unique benefits that made it superior to competitors.

3. This new service was considered a quality service compared to competing services.

Cost position (Cronbach $\alpha=.95)$

Cost position was assessed by means of two items that reflected the impact of the new financial service on cost efficiency.

1. This new service substantially lowered costs for the organization.

2. Through the introduction of this new service important cost efficiencies were achieved for the company.

\section{Organizational design variables}

The following scale instruction was provided on the questionnaire:

Shown below are a number of statements concerning the organizational structure in which the new service was developed. Along with each statement, you will find a scale. Please indicate how strongly you agree with each of the following statements, relative to the presently discussed project. Circle the scale value that best reflects your opinion.. $(1=$ strongly disagree to $5=$ strongly agree)

Top Management Support (Cronbach $\alpha=.90)$ 
Top management support was operationalized by means of a two-item scale partly based on case study research findings and partly on scale development by Souder and Moenaert [1991 - Interprod $\left.{ }^{2}\right]$.

1. The whole innovation process for this new service was characterized by strong support and involvement from top management.

2. Top management was involved in the development and launch preparation of this project.

Cross functional interface (Cronbach $\alpha=.90)$

Cross-functional interface was adapted from Mahajan et al. (1994) and Pinto, Pinto and Prescott (1993).

1. This project showed active involvement of all parties involved.

2. Cooperation between project members was characterized by a steady and fluent exchange of resources (money, personnel, equipment, office space).

3. Work flow (materials, objects and customers) was easily transferred between the project members involved.

4. An excellent interaction was present between the members involved for the transfer of information.

\section{Organizational diversity (Cronbach $\alpha=.80)$}

Organizational diversity was partly based on the operationalization of Gupta and Wilemon (1986).

1. This project involves cooperation from different functional specialists.

2. The development of this new service was characterized by the involvement of a wide range of specialist skills including marketing, operations and technical personnel.

3. The project required skills and professional inputs from a diversity of functional departments.

4. The project members involved during development of this project were selected because of their specialist skills within their respective fields.

\section{Participative decision making (Cronbach $\alpha=.55)$}

Participative decision making was assessed through existing measures (Gupta, Raj and Wilemon, 1986; Walton, 1981; Roberts and O'Reilly, 1974; Dewar, Whetten and Boje, 1980).

1. Top management delegated responsibilities for the tasks involving this project.(R)

2. Top management encouraged project personnel to make suggestions.(R)

\section{Quality of the New Service Innovation Process (No reliability coefficient is given as it is measured by one item only)}

The former mentioned InterProd questionnaire proved to be an inspiration in the design of a scale to examine the impact of the quality of the new service development activities on new financial service success. The innovation process goes through different stages ranging from the invention of a new service idea, over service development till the final launch of the new service. The following scale instruction was provided on the questionnaire: Shown below are statements concerning the quality of the activities during the respective stages of the innovation project. Along with each stage, you will find a scale. Please indicate how good or bad the activities have been. Circle the scale value that best reflects your opinion. $(1=v e r y$ bad, 2 = bad, 3 = neither bad nor good, $4=$ good, $5=$ very good)

Three stages can be distinguished:

a) A planning stage or pre-development stage involving activities such as idea generation and idea screening, a business analysis including a market and technical assessment of the new service as well as concept development and testing.

b) A development stage involving activities such as service design and process development for production and delivery of the service, in-house testing and determination of the marketing program.

c) A launch stage involving activities such as personnel training, a pilot run and test marketing in a few branches of the company.

How well were the activities undertaken (a) in the planning stage, (b) in the development stage, (c) in the launch stage?

An (R) indicates that these items were reverse coded.

\footnotetext{
${ }^{2}$ Interprod is an international research project [e.g., US, Belgium, The Netherlands, Germany, Japan, Singapore] aimed at acquiring insight into management of innovation. Cross-cultural differences are expected to affect the way innovation activities are handled in the different countries involved. Moreover, insight will be obtained into the critical innovation success factors in those countries.
} 
Nature of

Communication

Performance

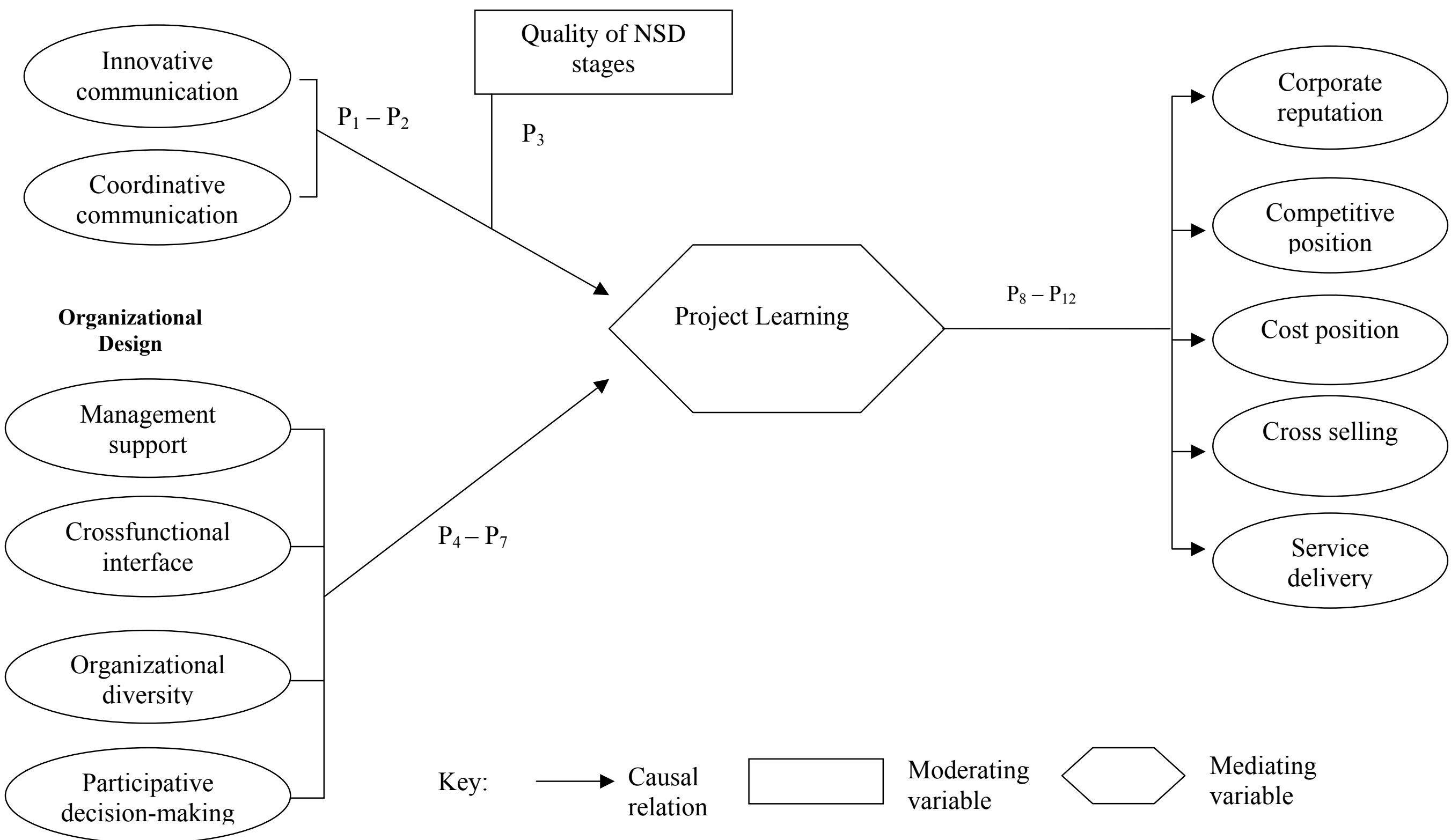


TABLE 1

Correlation Matrix between Learning, the Nature of Communication and the New Service Development Process

\begin{tabular}{|c|c|c|c|c|c|c|c|}
\hline Variable & Mean & S.D. & $\begin{array}{c}\text { Innovative } \\
\text { Communication }\end{array}$ & $\begin{array}{c}\text { Coordinative } \\
\text { Communication }\end{array}$ & $\begin{array}{l}\text { Quality of the } \\
\text { Planning Stage }\end{array}$ & $\begin{array}{c}\text { Quality of the } \\
\text { Development } \\
\text { Stage }\end{array}$ & $\begin{array}{l}\text { Quality of the } \\
\text { Launch Stage }\end{array}$ \\
\hline $\begin{array}{l}\text { Innovative } \\
\text { Communication }\end{array}$ & 3.65 & 0.66 & - & & & & \\
\hline $\begin{array}{l}\text { Coordinative } \\
\text { Communication }\end{array}$ & 3.76 & 0.71 & $.558 * * *$ & - & & & \\
\hline $\begin{array}{l}\text { Quality of the } \\
\text { Planning Stage }\end{array}$ & 3.74 & 0.97 & $.249 *$ & $.517 * * *$ & - & & \\
\hline $\begin{array}{l}\text { Quality of the } \\
\text { Development Stage }\end{array}$ & 3.81 & 0.92 & $.482 * * *$ & $.429 * * *$ & $.282 *$ & - & \\
\hline $\begin{array}{l}\text { Quality of the } \\
\text { Launch Stage }\end{array}$ & 3.67 & 1.18 & $.344 * *$ & $.614 * * *$ & $.414 * * *$ & $.576 * * *$ & - \\
\hline Project Learning & 3.57 & 0.84 & $.381 * * *$ & $.282 *$ & .189 & $.324 * * *$ & .142 \\
\hline
\end{tabular}

Key: Table entries represent pearson product moment correlations. Using pairwise deletion, the sample size varies between 63 and 65 .

Asterisks indicate the level of significance: ${ }^{* * *} \mathrm{p}<.001,{ }^{* *} \mathrm{p}<.01,{ }^{*} \mathrm{p}<.05$. Hypothesized correlations in bold print. 
TABLE 2

Hierarchical Regression of the Moderating Effect of the New Service Development Process

\begin{tabular}{|c|c|c|c|c|c|c|}
\hline Interaction terms & $\begin{array}{l}\text { Significant } \\
\text { interaction }\end{array}$ & $\begin{array}{c}\text { Sign } \\
\text { Interaction term }\end{array}$ & R-square adjusted & R-square change & F change & $\begin{array}{c}\text { Significance } \\
\text { F-change }\end{array}$ \\
\hline Innov_qualp & Yes & Positive & .128 & .039 & 2.73 & $\mathrm{p}<.1$ \\
\hline Coord_quald & No & Positive & .111 & .007 & 0.27 & n. s. \\
\hline Coord_quall & No & Negative & .082 & .004 & 0.15 & n. s. \\
\hline
\end{tabular}

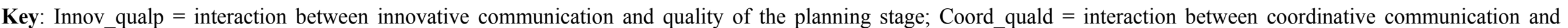

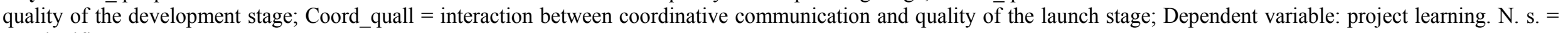
not significant 
TABLE 3

Correlation Matrix between Project Learning and Organizational Antecedents

\begin{tabular}{|c|c|c|c|c|c|c|}
\hline Variable & Mean & S.D. & $\begin{array}{c}\text { Top } \\
\text { Management } \\
\text { Support }\end{array}$ & $\begin{array}{l}\text { Cross-functional } \\
\text { Interface }\end{array}$ & $\begin{array}{l}\text { Organizational } \\
\text { Diversity }\end{array}$ & $\begin{array}{c}\text { Participative } \\
\text { Decision-Making }\end{array}$ \\
\hline $\begin{array}{l}\text { Top Management } \\
\text { Support }\end{array}$ & 3.67 & 1.05 & - & & & \\
\hline $\begin{array}{l}\text { Cross-functional } \\
\text { Interface }\end{array}$ & 3.85 & 0.80 & $.529 * * *$ & - & & \\
\hline $\begin{array}{l}\text { Organizational } \\
\text { Diversity }\end{array}$ & 3.93 & 0.71 & $.305 * *$ & $.449 * * *$ & - & \\
\hline $\begin{array}{l}\text { Participative } \\
\text { Decision-Making }\end{array}$ & 3.71 & 0.89 & $.579 * * *$ & $.555 * * *$ & $.328 * *$ & - \\
\hline Project Learning & 3.57 & 0.84 & $.502 * * *$ & $.260 *$ & $.319 * *$ & $.338 * *$ \\
\hline
\end{tabular}

Key: Table entries represent pearson product moment correlations. Using pairwise deletion, the sample size varies between 63 and $64 . \quad$ Asterisks indicate the level of significance: $* * * \mathrm{p}<.001, * * \mathrm{p}<.01, * \mathrm{p}<.05$. Hypothesized correlations in bold print. 


\section{TABLE 4}

Correlation Matrix between Project Learning and Performance Measures

\begin{tabular}{|c|c|c|c|c|c|c|c|}
\hline Variable & Mean & S.D. & $\begin{array}{l}\text { Corporate } \\
\text { Reputation }\end{array}$ & $\begin{array}{l}\text { Competitive } \\
\text { Position }\end{array}$ & Cost Position & Cross-selling & $\begin{array}{c}\text { Service Delivery } \\
\text { Capacity }\end{array}$ \\
\hline $\begin{array}{l}\text { Corporate } \\
\text { Reputation }\end{array}$ & 3.63 & 1.06 & - & & & & \\
\hline $\begin{array}{l}\text { Competitive } \\
\text { Position }\end{array}$ & 3.32 & 1.03 & $.758 * * *$ & - & & & \\
\hline Cost Position & 2.51 & 1.08 & $.282 *$ & $.364 * *$ & - & & \\
\hline Cross-selling & 2.73 & 0.95 & $.705^{* * *}$ & $.704 * * *$ & $.341 * *$ & - & \\
\hline $\begin{array}{l}\text { Service Delivery } \\
\text { Capacity }\end{array}$ & 3.23 & 0.99 & $.670 * * *$ & $.699 * * *$ & $.572 * * *$ & $.701 * * *$ & - \\
\hline Project Learning & 3.57 & 0.84 & $.519 * * *$ & $.610 * * *$ & $.553 * * *$ & $.451 * * *$ & $.727 * * *$ \\
\hline
\end{tabular}

Key: Table entries represent pearson product moment correlations. Using pairwise deletion, the sample size varies between 63 and 64 .

Asterisks indicate the level of significance: $* * * \mathrm{p}<.001, * * \mathrm{p}<.01, * \mathrm{p}<.05$. Hypothesized correlations in bold print. 
Table 5: Correlation Matrix of all Variables

\begin{tabular}{|c|c|c|c|c|c|c|c|c|}
\hline Variable & $\begin{array}{l}\text { Project } \\
\text { Learning }\end{array}$ & $\begin{array}{l}\text { Innovative } \\
\text { comm. }\end{array}$ & $\begin{array}{l}\text { Coordinative } \\
\text { Comm. }\end{array}$ & $\begin{array}{l}\text { Corporate } \\
\text { Reputation }\end{array}$ & $\begin{array}{l}\text { Competitive } \\
\text { Position }\end{array}$ & Cost Position & Cross-selling & $\begin{array}{l}\text { Service } \\
\text { Delivery } \\
\text { Capacity }\end{array}$ \\
\hline Innovative comm. & $.381 * * *$ & & & & & & & \\
\hline Coordinative Comm. & $.282 * *$ & $.558 * * *$ & & & & & & \\
\hline Corporate Reputation & $.519 * * *$ & $.291 *$ & $.312 * *$ & & & & & \\
\hline Competitive Position & $.610^{* * *}$ & $.532 * * *$ & $.375^{* *}$ & $.758 * * *$ & & & & \\
\hline Cost Position & $.553 * * *$ & $.300 * *$ & $.264 *$ & $.282 *$ & $.364 * *$ & & & \\
\hline Cross-selling & $.451 * * *$ & .169 & $.250 *$ & $.705^{* * *}$ & $.704 * * *$ & $.341 * *$ & & \\
\hline $\begin{array}{l}\text { Service Delivery } \\
\text { Capacity }\end{array}$ & $.727 * * *$ & $.319 * *$ & $.289 *$ & $.670 * * *$ & $.699 * * *$ & $.572 * * *$ & $.701 * * *$ & \\
\hline Management Support & $.502 * * *$ & $.475^{* * *}$ & $.379 * *$ & $.443 * * *$ & $.599 * * *$ & $.334 * *$ & $.406 * *$ & $.514 * * *$ \\
\hline $\begin{array}{l}\text { Cross-functional } \\
\text { interfaces }\end{array}$ & $.260 *$ & $.534 * * *$ & $.677 * * *$ & $.285^{*}$ & $.329 * *$ & $.232 *$ & .150 & $.329 * *$ \\
\hline $\begin{array}{l}\text { Organizational } \\
\text { Diversity }\end{array}$ & $.319^{* *}$ & $.515 * * *$ & $.509^{* * *}$ & $.219^{*}$ & $.289 *$ & $.274^{*}$ & .176 & $.221^{*}$ \\
\hline $\begin{array}{l}\text { Participative } \\
\text { Decision-making }\end{array}$ & $.338 * *$ & $.375^{* *}$ & $.515^{* * *}$ & $.272 *$ & $.299 * *$ & $.220 *$ & .179 & $.274^{*}$ \\
\hline
\end{tabular}

Key: Table entries represent pearson product moment correlations. Using pairwise deletion, the sample size varies between 62 and 64 . Asterisks indicate the level of significance: $* * * \mathrm{p}<.001, * * \mathrm{p}<.01, * \mathrm{p}<.05$. Hypothesized correlations in bold print. 
Table 6: Partial Correlation Matrix of all Variables controlling for Project Learning

\begin{tabular}{|c|c|c|c|c|c|c|c|c|c|c|c|c|}
\hline \multirow[t]{2}{*}{ Variable } & \multicolumn{2}{|c|}{$\begin{array}{c}\text { Innovative } \\
\text { Communication }\end{array}$} & \multicolumn{2}{|c|}{$\begin{array}{c}\text { Coordinative } \\
\text { Communication }\end{array}$} & \multicolumn{2}{|c|}{$\begin{array}{l}\text { Management } \\
\text { Support }\end{array}$} & \multicolumn{2}{|c|}{$\begin{array}{c}\text { Cross-functional } \\
\text { interfaces }\end{array}$} & \multicolumn{2}{|c|}{$\begin{array}{l}\text { Organizational } \\
\text { Diversity }\end{array}$} & \multicolumn{2}{|c|}{$\begin{array}{c}\text { Participative } \\
\text { Decision-making }\end{array}$} \\
\hline & Pearson+ & Partial++ & Pearson+ & Partial++ & Pearson+ & Partial++ & Pearson+ & Partial++ & Pearson+ & Partial++ & Pearson+ & Partial++ \\
\hline Corporate Reputation & $.291 *$ & .142 & $.312^{* *}$ & .198 & $.433 * * *$ & $.252 *$ & $.285^{*}$ & .161 & $.219 *$ & .080 & $.272 *$ & .114 \\
\hline Competitive Position & $.532 * * *$ & $.418 * * *$ & $.375 * *$ &. $.266^{*}$ & $.599 * * *$ & $.427 * * *$ & $.329 * *$ & $.222 *$ & $.289 *$ & .128 & $.299 * *$ & .124 \\
\hline Cost Position & $.300 * *$ & .124 & $.264^{*}$ & .133 & $.334 * *$ & .088 & $.232 *$ & .115 & $.274 *$ & .131 & $.220 *$ & .040 \\
\hline Cross-selling & .169 & .028 & $.250 *$ & .135 & $.406 * *$ & $.233^{*}$ & .150 & .041 & .176 & .058 & .179 & .021 \\
\hline $\begin{array}{l}\text { Service Delivery } \\
\text { Capacity }\end{array}$ & $.319 * *$ & .087 & $.289 *$ & .120 & $.514 * * *$ & $.249 *$ & $.329 * *$ & .127 & $.221 *$ & .006 & $.274^{*}$ & .122 \\
\hline
\end{tabular}

Key: Asterisks indicate the level of significance: $* * * p<.001, * * p<.01, * p<.05$.

+ Pearson means the Pearson zero order correlation coefficient; ++ Partial means partial correlations controlling for project learning

Key: Table entries represent pearson product moment correlations. Using pairwise deletion, the sample size varies between 62 and 64 . Asterisks indicate the level of significance: $* * * \mathrm{p}<.001, * * \mathrm{p}<.01, * \mathrm{p}<.05$. Hypothesized correlations in bold print. 